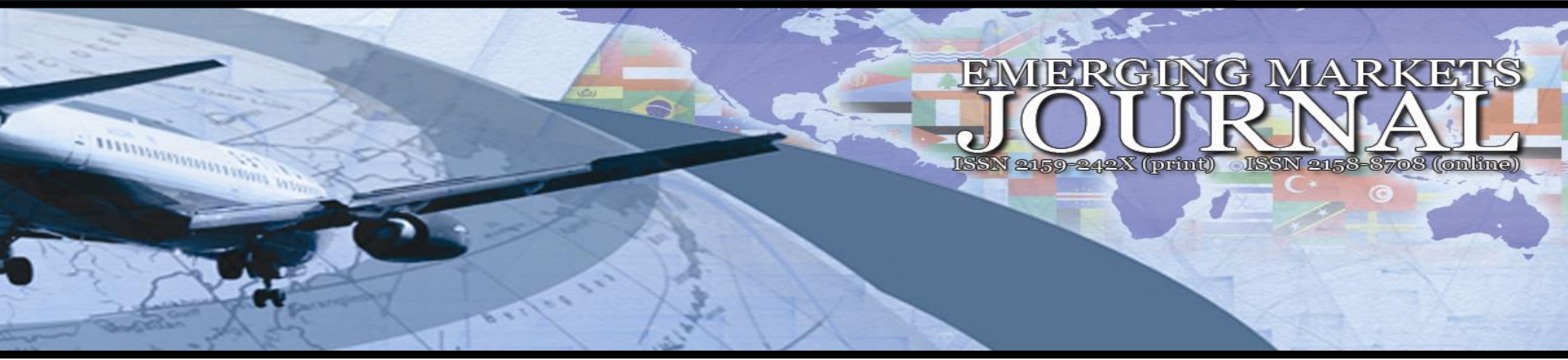

\title{
A Field Research to Identify Psychological Factors Influencing the Debt Repayment Behavior in Turkey
}

\author{
Mehtap Özşahin \\ Yalova University, Turkey | mehtap.ozsahin@yalova.edu.tr
}

\section{Senay Yürür}

Yalova University, Turkey | senay.yurur@yalova.edu.tr

\section{Erman Coskun}

Mohammed Bin Salman College of Entrepreneurship and Business, Saudi Arabia| Ecoskun@mbsc.edu.sa

Volume 8 No 2 (2018) ｜ ISSN 2158-8708 (online) | DOI 10.5195/emaj.2018.156 | http://emaj.pitt.edu |

\begin{abstract}
This research aims to exploratively search relevant psychological determinants for debt repayment behavior. In this regard, the research question is: Which psychological factors affect the debt repayment behavior? Some research in literature argue that the socio-economic factors alone may not be sufficient to explain debt and repayment behavior, and some other factors should be also utilized. This study will focus on psychological factors consisting of personality and attitudes. To the our best knowledge, in Turkey there is very limited amount of research conducted in this area and as one of the highest individual credit using countries it is essential to use psychological factors in credit risk evaluation processes. Thus, this research, examines effects of personality characteristics and attitude on debt repayment behavior in the context of Turkish culture, and is expected to fill a gap and to contribute to both national and international literatures. The study utilizes qualitative research methodology to explore psychological determinants and their effects on debt repayment behavior. In depth interview research methodology has been used to explore the personality characteristics and attitude influencing debt repayment behavior. The research findings revealed that, the responsibility, long term orientation, sanction fear, sense of collectivism, rational decision making and risk aversion are main characteristics of regular payers, while external locus of control, irresponsibility, short term orientation, irrational decision making, emotional imbalance are common characteristics of irregular payers. So, according to findings, , conscientious, time orientation, sanction fear, sense of collectivism, locus of control and decision making style can be enlisted as primary personal and attitudinal factors explaining the repayment behavior.
\end{abstract}

Keywords: Debt repayment, personality, attitude, psychological factors, qualitative method

\section{$(\mathrm{cc}) \mathrm{BY}$}

New articles in this journal are licensed under a Creative Commons Attribution 3.0 United States License.

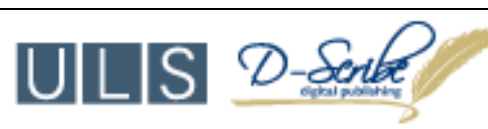

This journal is published by the University Library System of the University of Pittsburgh as part of its D-Scribe Digital Publishing Program, and is cosponsored by the University of Pittsburgh Press. 


\section{A Field Research to Identify Psychological Factors Influencing the Debt Repayment Behavior in Turkey}

\section{Mehtap Özşahin \\ Senay Yürür Erman Coșkun}

\section{Introduction}

In practice, most of the financial institutions make credit decisions based on socio economic or demographic data and they do not use personality related factors in credit granting process. According to interactionist perspective in psychology, individuals' behaviors are traced by not only environmental and situational factors, but also individuals' needs and personality traits. Based on this approach, it is apparent that individuals' personality traits can be featured as primary determinants of debt repayment behavior. However, in practice, most of the financial institutions do not use personality related factors in credit granting process and to the best of our knowledge, there are a few studies in this area. These facts were the motivation of this study.

In practice, customers' financial history is the first variable considered in credit score assessment and decisions. If a person does not have any registered credit or financial history, other possible indicators such as socio economic and demographic factors including income level, spending attitude, occupation, etc. are considered by credit assessors. The main objective of including those socio-economic and demographic factors in assessment process is to predict debt repayment behavior of a person. In last decade, besides socioeconomic and demographic factors, psychological factors consisting of personality traits, attitudes and behaviors have been emphasized as potential predictors of repayment behavior in debt related studies. Self-esteem, self-efficacy, locus of control, attitudes towards money and debt, risk attitude, financial literacy, time horizon, social comparison and compulsive buying behavior are some of the psychological factors examined by researchers to explain problematic debts (Vieira,
Rovedder de Oliveira and Kunkel, 2016; Harrison, Agnew and Serido, 2015; Achtziger, Hubert, Kenning, Raab and Reisch, 2015; Stumm, O'Creevy and Furnham, 2013; Rogers, Rogers and Securato, 2015; Arya, Eckel and Wichman, 2013; Gathergood,2012; Wang,Lu \& Malhotra, 2011; Mewse, Lea and Wrapson, 2010; Lusardi and Tofano, 2009; Stone and Maury, 2006).

Previous research on this issue mostly focused on economic and sociological predictors of repayment behavior. In 2000's, psychological factors along with economic and sociological factors have been started to be considered to explain the debt related behaviors (Kamleitner et al., 2012). Moreover, while Robb and Sharpe (2009) indicate the inadequacy of socio-economic factors in explaining the debt level; Wang et al. (2011) argued that psychological factors involving personality traits (Lea et al., 1993, Norvilitis et al., 2006; Webley, 1994) and attitude factors (Lea et al., 1993; Livingstone \& Lunt, 1992; Zhu and Meeks, 1994) still needed to be examined.

In Turkey, even though there is no relevant research directly focusing on the relationship between psychological factors and repayment behavior; a few studies examining the effects of behavioral and demographic factors on credit card use, debt level, debt structure have been conducted (eg. Özkan, 2014; Kaptan, 2011).

Among psychological factors, personality traits and attitudes are more significant ones to be associated to debt and debt repayment behavior and they have been scarcely studied in literature. In this context, this study, aiming to identify personality traits and attitudes affecting debt repayment behavior exploratively, is expected to contribute and help to fill a gap in literature. Moreover, findings of this research are expected to reveal repayment related psychological factors special to Turkish Culture, which also makes this study valuable.

\section{Literature Review and Theoretical Framework}

According to dispositional approach, individuals possess stable traits that influence their behaviors (DavisBlake and Pfeffer, 1989). These traits are primarily unobservable dispositions or mental states like values, needs or personalities. From this perspective, it can be said that personality and psychological states may have an effect on debt-repayment behavior of an individual. In addition to this, in the literature it is argued that socioeconomic factors are not enough to explain debt 
repayment behavior of individuals. Psychological factors need to be considered for understanding and explaining these behaviors (Wang et al., 2011; Robb and Sharpe, 2009).

Sullivan (1982)'s research, conducted with 1250 bankrupt participants, has been considered more comprehensive and initiating research on this subject. The research findings revealed that unexpected healthcare costs, wedding expenses and dismissal from job as main factors result in repayment default, correspondingly bankruptcy. One year after Sullivian and Schuchman (1983) repeated the research, and found that besides medical costs, irresponsible credit card use also leaded to default. Later, Dessart and Kuylen (1986) conducted a survey on 400 participants who failed to repay and stated external locus of control and financial illiteracy as main characteristics of those people. Those respective researches have brought out the low education level, low income level, young age, financial illiteracy, unexpected healthcare and wedding expenses, loosing job as predictors of payment default (Tokunaga, 1993).

Lea et al. (1993) indicated that psychological factors involving social comparisons, social support for debt, economic socialization, social comparisons, money management style, locus of control, attitudes, time horizon are associated with debt extensively. Parallel to Lea et al., Livingstone and Lunt (1992: 132) also stated that people making payments regularly are more concerned with personal achievement and self-direction, and they are more likely to see their debts as temporary, caused by external, unstable and uncontrollable disasters rather than stable causes like greed or the convenience of credit. Finally, they usually have positive attitude towards credit and reject the shame view of debt. Similarly, Norvilitis et al. (2006) searched factors like personality traits, attitudes towards debt and financial literacy as the predictors of greater debt (credit card debt) and found out that financial illiteracy is more influential factor leading problematic debt.

Briefly, in previous studies, personality factors, like self-control, self-esteem, self-efficacy, sensation seeking, deferring gratification, impulsiveness and locus of control, and attitude factors, like money attitude, debt attitude, credit attitude, satisfaction with life, have been come out as predominant factors influencing repayment behavior (Wang et al., 2011).

The studies conducted in Turkey, mostly examined the effects of behavioral and demographic factors on credit card use, debt level, debt structure rather than focusing on the direct relationship between psychological factors and repayment behavior. For example, Kaptan (2011) evaluated the households' attitudes towards consumer credits and their repayment behavior by analyzing 184.603 open and close consumer credit data obtained from 194.143 customers of a Turkish Commercial Bank. Moreover, Özkan's (2014) research, aiming to investigate the main characteristics of credit card users, revealed that financial illiteracy, gender, age, income level, occupation, and irrationality are more related factors to debt litigation.

The absence of research focusing on the relationship of psychological factors to debt repayment behavior in Turkey and insufficiency of socio-economic factors in explaining debt and repayment behavior, indicate the essentiality of this research, investigating psychological determinants of repayment behavior.

\section{Research Method}

This study, aiming to explore psychological factors related to repayment behavior, utilizes qualitative research method. Recently, qualitative researches have increased in importance in social science. It is commonly accepted that qualitative and quantitative research methods complete each other to explain social circumstances and incidents. Qualitative research methods, such as in depth interview and focus group, emphasize to describe events and phenomena in their natural environment, to understand and reflect participants' view with an inductive and interpretive approach. Thus, qualitative research methods are commonly used in initial stage of research in social science and detailed data obtained from qualitative research (eg. focus groups or depth interview) constitute a base for quantitative research like questionnaires (Kitzinger, 1995). Therefore this study used in depth interview to reveal Turkish culture and socio-economic structure specific personal traits, attitudes and behaviors affecting repayment behavior.

In this context, at first phase of research, in depth interview method was used. The researchers, using purposive sampling, targeted three types of sample groups to interview: (1) "bank staff" who have authority to make credit decisions, along with interacting with individual customers one to one and have at least 5-years of experience in individual customer banking; (2)"regular payers" who have debtor-creditor relationship with a bank and pay his/her debts before or on due date; and (3) 
"irregular payers" who have debtor-creditor relationship with a bank but have some problems with paying his/her debts (eg. paying interest/fine because of late payment or facing debt litigation or attachment proceedings). Semi-structured interviews have been conducted with 10 participants. 2 participants, referred as "bank staff", are executives in individual customer banking department of 2 different banks; 7 participants, referred as "regular payer", pay their debts regularly and 1 participant, referred as "irregular payer", pays his debts occasionally. Demographic characteristics of participants are given in Table 1 below:

Table 1. Demographics of Participants

\begin{tabular}{|l|l|l|l|l|l|l|} 
Participant & Gender & Age & Education & Occupation & Marital Status & Sample Group \\
\hline P1 & Male & 38 & University Degree & Bank Staff & Married & Bank Staff \\
\hline P2 & Male & 58 & Master Degree & Financier & Married & Regular payer \\
\hline P3 & Female & 32 & Master Degree & Lecturer & Married & Regular payer \\
\hline P4 & Male & 40 & Ph.D. Degree & Academician & Single & Irregular payer \\
\hline P5 & Male & 34 & Ph.D. Degree & Academician & Single & Regular payer \\
\hline P6 & Male & 36 & $\begin{array}{l}\text { Elementary } \\
\text { School }\end{array}$ & $\begin{array}{l}\text { Blue Collar } \\
\text { Employee }\end{array}$ & Married & Regular payer \\
\hline P7 & Female & 48 & Ph.D. Degree & Academician & Married & Regular payer \\
\hline P8 & Male & 38 & Master Degree & Lecturer & Single & Regular payer \\
\hline P9 & Male & 46 & Master Degree & $\begin{array}{l}\text { White Collar } \\
\text { Employee }\end{array}$ & Married & Regular payer \\
\hline P10 & Male & 34 & University Degree & Bank Staff & Married & Bank Staff \\
\hline
\end{tabular}

Face to face interviews have been conducted and all interviews were recorded by digital voice recorder with the permissions of the participants. Participants were informed that all information they shared will be used just for academic purposes and will not be published without their permission. Respondents were asked different questions structured in different forms to explore and to identify distinctive personality traits, attitudes and behaviors of regular and irregular payers as depicted on following (Table 2):

Table 2. Sample Questions Asked to Respondents

\begin{tabular}{|c|c|c|c|}
\hline & $\begin{array}{ll}\begin{array}{l}\text { Regular } \\
\text { Respondent }\end{array} & \text { Payer } \\
\end{array}$ & \begin{tabular}{|l|l|}
$\begin{array}{l}\text { Irregular } \\
\text { Respondent }\end{array}$ & Payer \\
\end{tabular} & Bank Staff \\
\hline $\begin{array}{l}\text { To describe } \\
\text { Regular } \\
\text { Payers' } \\
\text { Characteristics }\end{array}$ & $\begin{array}{l}\text { 1. You said you pay your } \\
\text { debts regularly. What } \\
\text { motivates you to pay your } \\
\text { debts regularly? } \\
\text { 2. What internal or } \\
\text { extemal factors motivate } \\
\text { you to pay regularly? } \\
\text { 3. How do you describe } \\
\text { yourself in terms of } \\
\text { personality trait, attitudes, } \\
\text { behaviors etc. } \\
\text { 4. How do your relatives' } \\
\text { friends co-workers } \\
\text { describe you in terms of } \\
\text { personality trait, attitudes, } \\
\text { behaviors etc. }\end{array}$ & $\begin{array}{l}\text { 1. Do you have relatives or } \\
\text { friends paying their debts } \\
\text { regularly? } \\
\text { 2. What are the main } \\
\text { personality traits of those } \\
\text { people? } \\
\text { 3. Can you describe } \\
\text { distinctive attitudes and } \\
\text { behaviors of those people? } \\
\end{array}$ & $\begin{array}{l}\text { 1. What kind of people you } \\
\text { prefer to grant a loan? } \\
2 \text {. How can you describe a } \\
\text { regular payer? } \\
\text { 3. Based on your } \\
\text { experience in banking, can } \\
\text { you describe the main } \\
\text { personality traits of regular } \\
\text { payers? } \\
4 \text { Again based on your } \\
\text { experiences in banking, } \\
\text { can you describe } \\
\text { distinctive attitudes and } \\
\text { behaviors of regular } \\
\text { payers? }\end{array}$ \\
\hline $\begin{array}{l}\text { To describe } \\
\text { Irregular } \\
\text { Payers' } \\
\text { Characteristics }\end{array}$ & $\begin{array}{l}\text { 1. Have you ever not } \\
\text { received a loan back you } \\
\text { had lent to your relative or } \\
\text { your friend? } \\
\text { 2. What are the main } \\
\text { personality traits of this } \\
\text { person (those poople)? } \\
3 \text {. Can you describe } \\
\text { distinctive attitudes and } \\
\text { behaviors of this person } \\
\text { (those people)? }\end{array}$ & $\begin{array}{l}\text { 1. You said you usually } \\
\text { haven't pay your debts on } \\
\text { time. Why don't you pay } \\
\text { your debts regularly? } \\
\text { 2. What factors (internal or } \\
\text { external) impede you to } \\
\text { pay regularly? } \\
\text { 3. How can you describe } \\
\text { yourself? In terms of } \\
\text { personality trait, attitudes, } \\
\text { behaviors etc. } \\
\text { 4. How do your relatives } \\
\text { friends co-workers } \\
\text { describe you? In terms of } \\
\text { personality trait, attitudes, } \\
\text { behaviors etc. }\end{array}$ & $\begin{array}{l}\text { 1. What kind of people you } \\
\text { reject to grant loan? } \\
2 \text {. How can you describe } \\
\text { an irregular payer? } \\
3 \text {. Based on your } \\
\text { experience in banking, can } \\
\text { you describe the main } \\
\text { personality traits of } \\
\text { irregular payers? on your } \\
4 \text {. Again based on your } \\
\text { experience in banking, can } \\
\text { you describe distinctive } \\
\text { attitudes and behaviors of } \\
\text { irregular payers? }\end{array}$ \\
\hline
\end{tabular}

The voice recordings (93 minutes) were transcripted into a written document by researchers in the same day. Then, data obtained from 10 interviewees were coded and analyzed by 3 different researchers. For methodological soundness of this research, triangulation strategy (Denzin 1978) was followed. As purpose of triangulation (Jick 1979) strategy, firstly, data were gathered from different sources such as bank staff, regular payers and irregular payers, secondly, data were analyzed by 3 researchers individually.

For data analysis process, the framework of Miles and Huberman (1984) has been adopted. Miles and Huberman (1984) proposed that qualitative data analysis should include (1) data reduction (the process of selecting, focusing, simplifying, abstracting, and transforming the data that appear in written up field notes or transcriptions), (2) data display (an organized, compressed assembly of information through diagrams, charts or tables, and (3) conclusion drawing-verification (revisiting the data as many times as necessary and check the literature to cross-check or verify these emergent conclusions) processes.

In this direction, data obtained from 10 participants was grouped based on 2 main questions: (1) What are the main characteristics of regular payers?, and (2) What are the main characteristics of irregular payers. Then, those data were coded by 2 different researchers independently by using the open coding technique to ensure the inter-rater reliability (Armstrong, Gosling, Weinman, Marteau 1997). 85\% consistency is provided between two researchers' coding. The 3 rd researcher checked the coding, and coding differences among researchers were eliminated through reconciliation. Concepts provided by initial coding process, were subsumed into subcategories at second stage by the researchers jointly and the main characteristics of regular payers and irregular payers were categorized as depicted in Table 3. 
Table 3. Codes provided by Two-Step Coding Analyses

\begin{tabular}{|c|c|}
\hline $\begin{array}{l}\text { Regular Payers (Initial } \\
\text { Coding) }\end{array}$ & $\frac{\text { Regular }}{\text { (Subcategorization Coding) }}$ \\
\hline Responsibility (8) & \multirow{7}{*}{ Responsibility (23) } \\
\hline Punctual (3) & \\
\hline Prudent (3) & \\
\hline Dependable (3) & \\
\hline Planned (1) & \\
\hline Consistent (2) & \\
\hline Ethic value (3) & \\
\hline Long term orientation (5) & Long term orientation (5) \\
\hline $\begin{array}{l}\text { Rational Decision Making } \\
\text { (4) }\end{array}$ & \multirow{2}{*}{$\begin{array}{l}\text { Rational Decision Making } \\
\text { (5) }\end{array}$} \\
\hline Realist (1) & \\
\hline Sense of Collectivism (5) & Sense of Collectivism (5) \\
\hline Sanction Fear (4) & Sanction Fear (4) \\
\hline Risk aversion(2) & Risk aversion (2) \\
\hline Intolerant to stress (1) & Intolerant to stress \\
\hline $\begin{array}{lll}\begin{array}{l}\text { Internal } \\
\text { control(1) }\end{array} & \text { locus } & \text { of } \\
\end{array}$ & Internal locus of control \\
\hline Financial literacy (1) & Financial literacy \\
\hline Irregular Payers (Initial & $\frac{\text { Irregular } \quad \text { Payers }}{\text { (Subcategorization Coding) }}$ \\
\hline $\begin{array}{l}\text { External locus of control } \\
\text { (5) }\end{array}$ & \multirow[t]{2}{*}{$\begin{array}{l}\text { External locus of control } \\
\text { (7) }\end{array}$} \\
\hline Extraversion(2) & \\
\hline Irresponsible (4) & \multirow{2}{*}{ Irresponsible (6) } \\
\hline Dreamer (2) & \\
\hline Emotional imbalance & \multirow{2}{*}{ Emotional imbalance (2) } \\
\hline Inconsistent & \\
\hline Short term orientation (2) & \multirow{2}{*}{ Short term orientation (4) } \\
\hline Rambling (2) & \\
\hline $\begin{array}{ll}\text { Irrational } & \text { Decision } \\
\text { Making (2) } & \\
\end{array}$ & Irrational Decision Making \\
\hline Risk oriented (1) & Risk oriented \\
\hline Tolerant to stress (1) & Tolerant to stress \\
\hline Low self-esteem (1) & Low self-esteem \\
\hline Financial literacy (1) & Financial literacy \\
\hline Compulsive buying (1) & Compulsive buying \\
\hline $\begin{array}{l}\text { Addiction (e.g. Alcohol), } \\
\text { (1) }\end{array}$ & Addiction (eg. Alcohol) \\
\hline
\end{tabular}

At the last stage, subcategorized codes, namely main characteristics of regular payers and irregular payers, were consolidated into other subcategories to reveal themes. Table 4 indicates those themes revealed after refinement of subcategorized codes at third stage. Researchers also benefited from literature (e.g. big five personality traits, McCrae and Costa, 1987) while refining the codes.
Table 4. Themes Revealed by Refinement of Subcategorized Codes

\begin{tabular}{|l|l|l|}
\hline $\begin{array}{l}\text { Regular Payers } \\
\text { (Subcategorization Coding) }\end{array}$ & $\begin{array}{l}\text { Irregular Payers } \\
\text { (Subcategorization Coding) }\end{array}$ & Themes (Most effective Factors) \\
\hline Responsibility (23) & Iresponsible (6) & Conscientiousness (23+6) \\
\hline Long tem orientation (5) & Short term orientation (4) & Time Orientation (5+4) \\
\hline Intemal locus of control (1) & Extemal locus of control (7) & Locus of Control (1+7) \\
\hline Rational Decision Making (5) & $\begin{array}{l}\text { Irational Decision Making } \\
\text { (2) }\end{array}$ & Decision Making Style (5+2) \\
\hline Sense of Collectivism (5) & & Sense of Collectivism (5) \\
\hline Sanction Fear (4) & $\begin{array}{l}\text { Sanction Fear (Punishment } \\
\text { Avoidance) (4) }\end{array}$ \\
\hline $\begin{array}{l}\text { Risk aversion(2), Intolerant } \\
\text { to stress, Financial literacy (1 } \\
\text { for each) }\end{array}$ & $\begin{array}{l}\text { Emotional imbalance (2), } \\
\text { Risk oriented, Tolerant to } \\
\text { stress, Low self-esteem, } \\
\text { Financial literacy, } \\
\text { Compulive buying, } \\
\text { Substance addiction (1 for } \\
\text { each) }\end{array}$ & $\begin{array}{l}\text { Risk orientation, Emotional } \\
\text { imbalance, Stress Tolerance, } \\
\text { Financial literacy, Compulsive } \\
\text { buying, Low self-esteem, } \\
\text { Substance (Alcohol) addiction }\end{array}$ \\
\hline
\end{tabular}

\section{Findings}

Research findings revealed some common personality traits, attitudes and behaviors that differentiate regular payers from irregular ones. According to findings, the dominant characteristic of regular payers is "responsibility". Responsibility is coded 23 times to describe regular payers. For example, P6, a regular payer, describes his responsible characteristic with a statement of "When I have a debt, I can't sleep. I feel a hump on my back", while another regular payer $\mathrm{P} 9$, indicates that "If I promise to pay debt, I pay it on time. If I am not able to pay it on time, I usually call him and talk to him to notify him about not paying on time...... I don't buy a new thing if I did not pay my previous debt." P2 also describes himself as regular payer and responds the question of "Why do you pay your debts regularly?" by saying that "Because I am liable to pay it.... If you borrow anything else and promise to give back it on a stated date, you have to give back it on indicated time. This is liability.... an internal thing indeed".

"Rational decision making" is another prominent characteristics of regular payers, which is coded 5 times, while "irrational decision making" is revealed as characteristic of irregular payer, which is coded 2 times. Bank staff P1 tells how they identify regular payers by words of "those people had searched interest rates, insurance cost and other costs on internet before coming to bank.... So they evaluate how they would pay debt regularly.... On the other hand irregular payers does not care about interest rate, costs or other details, they just interest in whether they receive credit or not.... focus on receiving credit...". P10, bank staff describes the characteristics and behaviors of one regular payer by stating that "....he considers all alternatives in case of repayment default, and express those possibilities frankly....he is realist". 
Findings of interview research also displayed that regular payers commonly have "sense of collectivism" and "sanction fear", especially social sanction fear. Sense of collectivism is coded 5 times while sanction fear is coded 4 times to describe the regular payers. For instance, P2 indicated that if a relative of debtor stands security for debt, repayment possibility increase because debtor doesn't want to put relatives out and not to experience loss of publicity in his environment. P10, bank staff, also emphasized the role of "sense of collectivism" on regular paying behavior with the wording that "married people are more prone to pay regularly compared to single ones, because married people avoid making their family to experience execution of attachment... they perceive attachment as shame...." In terms of "sanction fear", P5 indicates that he pays debts on time or before due dates "not to pay a fine or penal interest...not to have bad reputation". Similarly, P8 stated he pays his debts on time "because system imposes higher fines.... cost of penal interest is scary".

Another common characteristic of regular payers, referring to "long term orientation", has also become evident by the findings of this research. While long term orientation is coded 5 times as attitudinal characteristic of regular payers; "short term orientation" is coded 4 times attitudinal characteristic of irregular payers. A regular payer respondent P2 displays his long term oriented characteristic with the wording that "Unless I pay my debt regularly, next step is cancellation of my credit cards which hurts my credit score. I can lose my credibility, which makes my life horrible in future. I don't want to live such a life, thus I pay my debts regularly". P3 also indicated that she pays regularly because she doesn't want her debts to increase exponentially and to become unpayable in future. On the other hand, P9 describes a "short term oriented" relative, who does not pay his debt on time by stating that "My uncle focus on moment and saving the day, does not think what will happen tomorrow".

The main characteristics of irregular payers have been founded as "external locus of control" and "irresponsibility" in this research, which are coded 7 times and 6 times respectively. On the other hand "internal locus of control" is coded 1 time as characteristic of regular payers. P1 and P10, bank staffs, state that irregular payers usually blame external factors or conditions for their payment failure. P9 also describe one of his relative, who don't pay his debt, with the words of "... he thinks he is usually cheated and abused by people. He does not consider his faulty in payment failure...he believes that God is put out with him, thus he failed in life". Moreover, the statement of "irregular payers always apply for credit with incomplete document" by P10, indicates another characteristic of irregular payers, the irresponsible behavior of irregular payers.

The concepts represents opposite tendencies (e.g. responsibility versus irresponsibility, long term orientation versus short term orientation) were consolidated into one theme. By benefiting from literature, characteristics of regular and irregular payers framed by findings of this survey, were refined into more comprehensive "themes" in order to reveal more influential factors on repayment behavior. In this direction, responsibility and irresponsibility is consolidated in term of "conscientiousness"; long term orientation and short term orientation in term of "time orientation"; external locus of control and internal locus of control in term of "locus of control"; and rational decision making and irrational decision making in term of "decision making style". Consequently, after refinement process of subcategorized codes, the findings of this survey revealed that conscientiousness, time orientation, locus of control, decision making style, sense of collectivism and sanction fear as the most influential psychological factors affecting debt repayment behavior (see Table 4).

\section{Conclusion and Discussions}

Is personality primary determinant of debt repayment behavior? Are the regular payers' personality characteristics different from of irregular payers' personality characteristics? What are the personality characteristics of regular payers and irregular payer? What are the most influential factors affecting debt repayment behavior? Researching the answers of those questions initiated this survey. The findings of this survey responded the first question in the affirmative, namely the findings of this survey revealed that personality is the primary determining factor of debt repayment behavior.

The primary finding of this qualitative descriptive study is the presence of dissimilarity between personality characteristics of regular payers and irregular payers. Findings displayed the main characteristics of regular payers as responsibility, long term orientation, sanction fear, sense of collectivism and rational decision 
making while external locus of control, irresponsibility, short term orientation, irrational decision making as common characteristics of irregular payers. Those finding are also consistent with the previous surveys' results indicating the effect of personality trait premise on behaviors of credit use and developing risky indebtedness, which result in the problem indebtedness (Vieira, Rovedder de Oliveira and Kunkel, 2016; Harrison, Agnew and Serido, 2015; Achtziger, Hubert, Kenning, Raab and Reisch, 2015; Stumm, O’Creevy and Furnham, 2013; Rogers, Rogers and Securate, 2013; Arya, Eckel and Wichman, 2013; Gathergood,2012; Wang,Lu \& Malhotra, 2011; Mewse, Lea and Wrapson, 2010; Lusardi and Tofano, 2009; Stone and Maury, 2006). So, previous studies have proposed individual's personality trait as the main determinants of attitudes towards debt. When those results are interpreted with the other research findings revealing the effects of situational factors, such as healthcare costs, wedding expenses and dismissal, on debt repayment behavior (Sullivan, 1982; Schuchman, 1983; Tokunaga, 1993), the multidimensional structure of repayment behavior becomes evident. In other words, debt repayment behavior is a multi-faced and sophisticated process, stemming from situational factors and individuals' personality traits.

The research findings revealed that conscientiousness is the primary determinant of debt repayment behavior. Moreover, responsibility is the main characteristics of regular payer, irresponsibility is common characteristics of irregular payers. Conscientiousness refers to tendency to be organized and dependable, show self-discipline, act dutifully, aim for achievement, and prefer planned rather than spontaneous behavior. According to Nyhus and Webley (2001), conscientious persons would be expected to keep track of their finance. Similarly, Livingstone and Lunt (1992) support the positive effect of conscientiousness on regular payment behavior by indicating that people who repaid regularly are more concerned with personal achievement and self-direction.

Time orientation, referring to the connection of the past with the current and future actions/challenges, has been emerged as another primary factor affecting debt repayment behavior, according to this survey's findings. Long term oriented people are more prone to pay their debts regularly, while short term oriented people unlikely have problems with payment of their debts regularly. Zhang and DeVaney (1999) supports those findings by their stating that short term oriented people, had larger amount of debt, are more likely to have debt payments difficulties. Those with a relatively high «subjective discount rate» are unlikely to be able to "defer gratifications" and thus will be less likely to save and more likely to incur debt (Lea, Webley and Walker, 1995).

The research findings also revealed that the external locus of control as main characteristics of irregular payers has been supported by literature (e.g. Dessart and Kuylen, 1986; Livingstone and Lunt, 1992). Livingstone and Lunt (1992) state that people having higher level of external locus of control are more prone to over-indebtedness. External locus of control, the characteristics of people who attribute what happens all in their life to the external factors (Spector, 1982), is appeared as trait of irregular payers and essential determinant of repayment behavior. Those people having external locus of control may avoid psychological pressure of debt by attributing the reasons of nonpayment to external factors rather than themselves, so, get rid of the responsibility in short therm. Another characteristic of irregular payers investigated by this research is short term orientation, is also completing the picture consistently.

As been indicated previously, the findings of this research on basic characteristics of regular and irregular payers are commonly consistent with international literature. However, "sense of collectivism" and "fear of sanction (punishment avoidance)", investigated by this research as trait of regular payers, are not relevant to international literature. Turkey has been classified as collectivist nation, involving "collectivist culture" by Hofstede (1980). In such a kind of collectivist cultures, individuals commonly feel that they have to obey the rules and values of group or society in which they live and mostly avoid the behaviors which are not accepted by the society and law. Thus, people who have intensive sense of collectivism will likely feel and respond to social pressure aroused from society intensively. In Turkish culture, "debt default" is still considered as a shame. Thus, in such a culture, individual who have high level of "sense of collectivism" and "fear of sanction", may be more prone to pay regularly to avoid social and legal pressures. Moreover, those who see credit and debt, as shameful, to be avoided, a source of problems, are people who build up their savings with their resources rather than servicing their debts with (Livingstone and Lunt, 1992), so are not getting problem with paying.

The underlying constraint of this study is failing to recruit a sufficient number of irregular payers. The 
number of irregular respondents can be increased by utilizing snowball sampling method to overcome this constraint in further researches. Moreover, the findings of this survey are limited to in depth interview analysis results of 10 participants. So, an extensive questionnaire survey, which based on findings of in depth interview research and literature review, can be conducted to verify the findings of this survey and to depict an overall picture of repayment behavior in Turkey.

\section{Acknowledgments [if any]}

This paper is presented at $8^{\text {th }}$ International Conference on Leadership, Technology, Innovation and Business Management 2018.

\section{References}

Achtziger, A., Hubert, M., Kenning, P., Raab, G. and Reisch, L. (2015). Debt out of control: The links between self-control, compulsive buying, and real debts. Journal of Economic Psychology 49:141-149.

Armstrong, D., Gosling, A., Weinman, J., \& Marteau, T. (1997). The place of inter-rater reliability in qualitative research: an empirical study. Sociology, 31(3), p. 597-606.

Arya, S., Eckel, C. and Wichman, C. (2013). Anatomy of the credit score. Journal of Economic Behavior \& Organization, 95:175- 185.

Denzin, N. K. (1978). The research act: a theoretical introduction to sociological methods. New York: Mcgraw Hill.

Dessart \& Kuylen (1986). The nature, extent, cause and consequence of problematic debt situations. Journal of Consumer Policy, 9, 311-334.

Gathergood, J. (2012). Self-control, financial literacy and consumer over-indebtedness. Journal of Economic Psychology 33: 590-602.

Harrison, N., Agnew, S. Serido, J. (2015). Attitudes to debt among indebted undergraduates:A crossnational exploratory factor analysis. Journal of Economic Psychology, 46: 62-73.

$$
\begin{array}{cccr}
\text { Hofstede, } \quad \text { G. } & (1980) . & \text { Culture } & \text { and } \\
\text { organizations. International } & \text { Studies } & \text { of } \\
\text { Management \& Organization, } & \text { 10(4), 15-41. } &
\end{array}
$$

Jick, T. D. (1979). Mixing qualitative and quantitative methods: triangulation in action. Administrative Science Quarterly, 24(4), p. 602-611.

Kamleitner, B., Hoelzl, E. and Kirchler, E. (2012), Credit Use: Psychological perspectives on a multifaceted phenomenon. International Journal of Psychology, Vol.47, Issue1, pp.1-27.
Kaptan, Özgür Burak (2011), Bireysel kredilerin risk ve tüketici davranışı açısından analizi, Doktora Tezi, Ankara Üniversitesi / Sosyal Bilimler Enstitüsü / İşletme Anabilim Dalı, Ankara.

Kitzinger, Jenny (1995).Qualitative Research: Introducing Focus Groups. BMJ (Clinical research ed.), 311:299-302.

Lea, E. G. S., Webley, P., \& Levine, R. M. (1993). The economic psychology of consumer debt. Journal of Economic Psychology, 14, 85-119.

Lea, S. E., Webley, P., \& Walker, C. M. (1995). Psychological factors in consumer debt: Money management, economic socialization, and credit use. Journal of economic psychology, 16(4), 681701.

Livingstone, M. S., \& Lunt, K. P. (1992). Predicting personal debt and debt repayment: Psychological, social and economic determinants. Journal of Economic Psychology, 13(1), 111-134.

Lusardi, A. and Tufano, P. (2009). Debt literacy, financial experiences, and overindebtedness, CFS Working Paper, No. 2009/08, (http://nbnresolving.de/urn:nbn:de:hebis:30-63796)

McCrae, R. R., \& Costa, P. T. (1987). Validation of the five-factor model of personality across instruments and observers. Journal of personality and social psychology, 52(1), 81.

Mewse, A.J., Lea, S.E.G. and Wrapson, W. (2010), First steps out of debt: Attitudes and social identity as predictors of contact by debtors with creditors. Journal of Economic Psychology 31:1021-1034.

Miles, M. B., \& Huberman, A. M. (1984). Drawing valid meaning from qualitative data: Toward a shared craft. Educational researcher, 13(5), 20-30.

Norvilitis, M. J., Merwin, M. M., Roehling, V. P., Young, P., \& Kamas, M. M. (2006). Personality factors, money attitudes, financial knowledge, and credit-card debt in college students. Journal of Applied Social Psychology, 36(6), 1395-1413.

Nyhus, E. K., \& Webley, P. (2001). The role of personality in household saving and borrowing behaviour. European journal personality, 15(S1), S85-S103.

Özkan, Canan (2014), Türkiye'de Kredi Kartı Kullanıcı Profili Ve Davranışı Analizi, Uzmanlık Yeterlilik Tezi, Türkiye Cumhuriyet Merkez Bankası Bankacılık ve Finansal Kuruluşlar Genel Müdürlügü, Ankara.

Robb, A. C., \& Sharpe, D. L. (2009). Effect of personal financial knowledge on college students' credit card behavior. Journal of Financial Counseling and Planning, 20(1), 25-34. 
Rogers, P., Rogers, D. and Securato, J.R. (2015). About Psychological Variables In Application Scoring Models. Revista de Administracao de Empresas, 55 (1): 38-49.

Shuchman, P., 1983. The average bankrupt: A description and analysis of 753 personal bankruptcy filings in nine states. Commercial Law Journal, 288-307.

Spector, P. E. (1982). Behavior in organizations as a function of employee's locus of control. Psychological bulletin, 91(3), 482.

Stone, B. and Maury, R. V. (2006), Indicators of personal Wnancial debt using a multi-disciplinary behavioral model. Journal of Economic Psychology 27: 543-556.

Stumm, S. O’Creevy, M.F. and Furnham, A. (2013). Financial capability, money attitudes and socioeconomic status: Risks for experiencing adverse financial events. Personality and Individual Differences 54:344-349.

Sullivan, AC., 1982. Consumer bankruptcy study II: Personal bankruptcy: Causes, costs, and benefits (Monograph No. 24). Purdue University: Credit Research Center.

Tokunaga, H. (1993). The use and abuse of consumer credit: Application of psychological theory and research. Journal of Economic Psychology, 14, 285-316

Vieira, K.M., Rovedder de Oliveira, M.O. and Kunkel, F. I. R. (2016). The Credit Card Use and Debt: Is there a trade-off between compulsive buying and ill-being perception? Journal of Behavioral and Experimental Finance, 10:75-87.

Wang, L., Lu, W. and Malhotra, N.K.(2011), Demographics, attitude, personality and credit card features correlate with credit card debt: A view from China, Journal of Economic Psychology 32: 179-193.

Webley, P. (1994). The role of economic and psychological factors in consumer debt. In: Progress Report 21. VSB-CentER Savings Project, Tilburg University, the Netherland (In Wang et al., 2011,Demographics, attitude, personality and credit card features correlate with credit card debt: A view from China, Journal of Economic Psychology 32: 179-193).

Zhang, T., \& DeVaney, S. A. (1999). Determinants of consumer's debt repayment patterns. Consumer Interest Annual, 45, 65-70.

Zhu, Y. L., \& Meeks, B. C. (1994). Effect of low-income families ability and willingness to use consumercredit on subsequent outstanding credit balance. Journal of Consumer Affairs, 28(2), 403-422. 